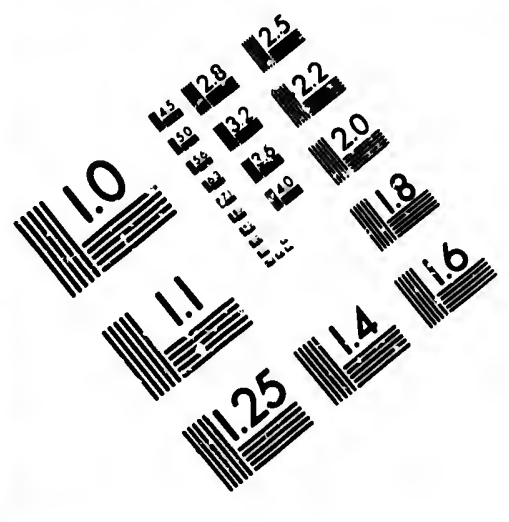

IMAGE EVALUATION

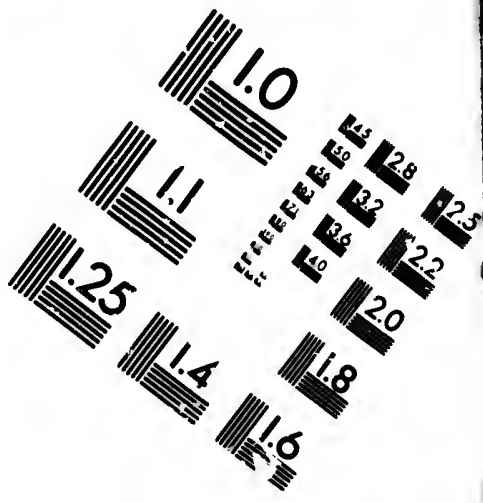

TEST TARGET (MT-3)
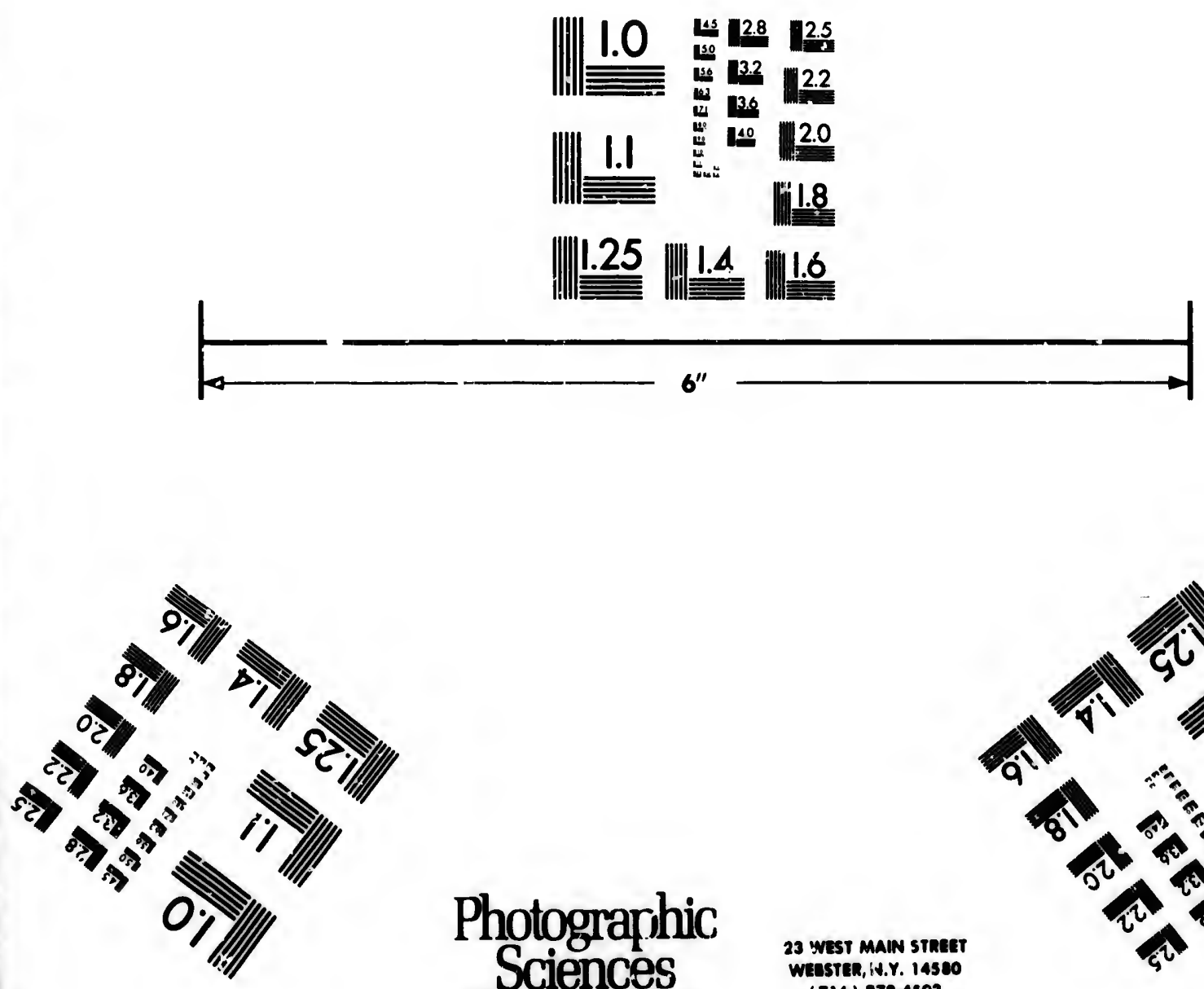

Photographic Sciences Corporation

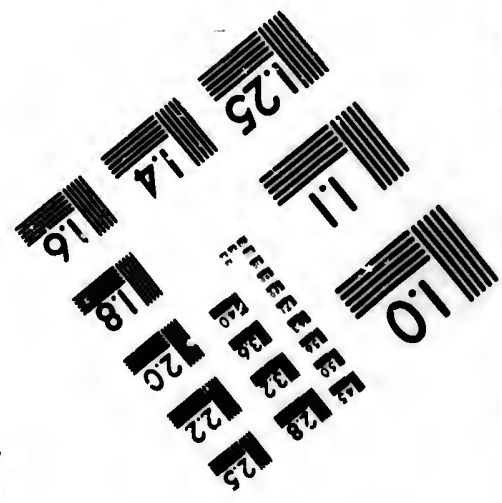




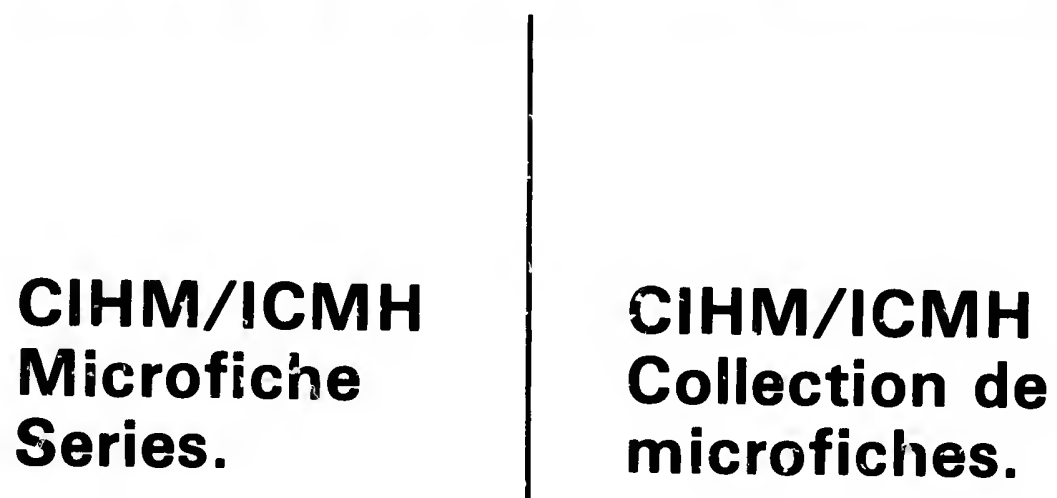

Canadian Institute for Historical Microreproductions / Institut canadien de microreproductions historiques
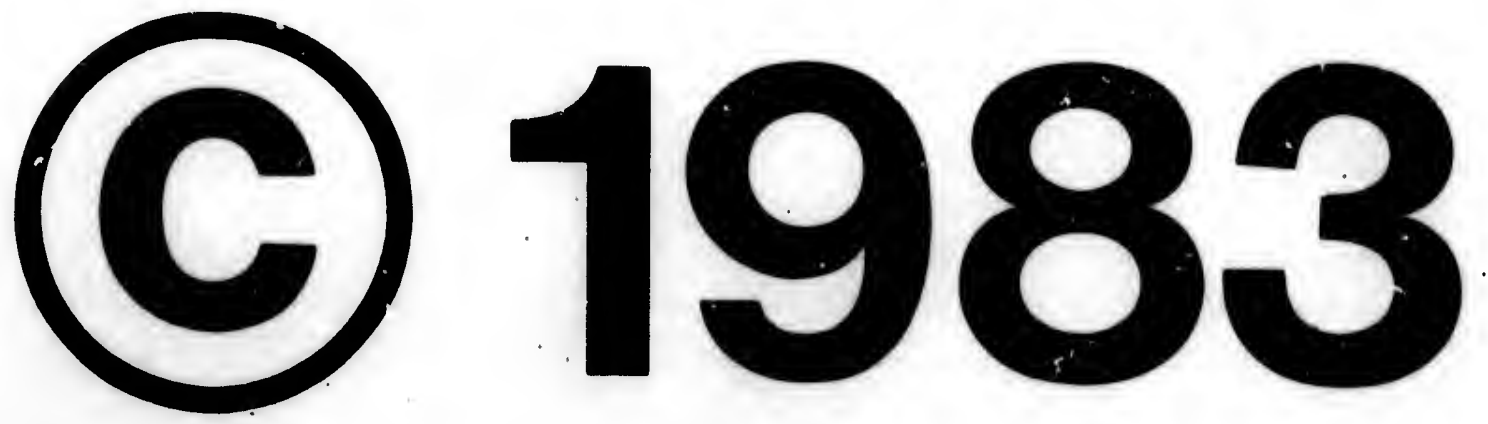
The Institute has attempted to obtain the best original copy avalabie for filming. Foatures of this copy which may be bibllographicaliy unique. which may alter any of the images in the reproduction, or which may significantly change the usual method of filming, are checked below.

\section{Coloured covers/}

Couverture de couleur

\section{Covers damaged/}

Couverture endommagée

Covers restored and/or laminated/

Coliverture restaurse et/ou peiliculé

Cover titie missing/

Le titre de couverture manque

Coloured maps/

Cartes géographiques en couleur

Coloured ink (i.e. other than blue or black)/

Encre de couleur (i.e. autre que bleus ou noire)

Coloured plates and/or iliustrations/

Pianches ot/ou illustrations en coulour

Bound with other material/

Relic avec d'outres decuments

Tight binding may cause shadows or distortion along interior margin/

La re liure serré peut causer de l'ombre ou de la distortion le long de la marge intórieure

Blank leaves added during rastoration moy appsar within the text. Whenover possible, these have been omitted from fliming/

II se peut que certaines pagus blanches ajoutces lore d'une restauration apparaiseont dans le toxte. mols, lorsque cola stbit posalble, ces pages n'ont pas sté flimoses.

Additional comments:/

Commentalres supplémentaires:
L'Institut a microfilmo lo meilleur exempiaire qu'il lui a eté possible de se procurer. Les dótails de cet exemplaire qui sont peut-être uniques du point de vue bibliographique, qui peuvènt modifier une image reproduite, ou qui peuvent exiger une modification dana la móthode normale de filmage sont indlqués cl-dessous.

\section{Coloured pages/}

Pages de couleur

Pages damaged/

Pages endommagées

Pages reatored and/or laminated/ Pages restaurces ot/ou peillculées

Pages diacoloured, stained or foxed/

Pages d́́colorées, tachetbes ou piquées

Pages detached/

Pages dótachóa

\section{Showthrough/}

Transparence

\section{Quelity of print varies/}

Qualité inogalo de l'impression

Includes aupplementary material/

Comprend du matóriel supplómentaire

Only edition avaliable/

Seule cidition disponible

Pages wholly or partially obscured by errata slips, tiscues, otc.. hove been rofilmed to onaure the beat possible imago/ Les pages totalement ou partiallement obecurcles par un foulliet d'errata, une pelure, etc.. ont stó fllmós a nouvesu de facon obtenir la moilleure Image posalbio.

This item lo filmed at the reduction ratio checked below/ Co document est fllmb au taux do reduction Indliqus el-dessous.

$203 x$

$30 x$

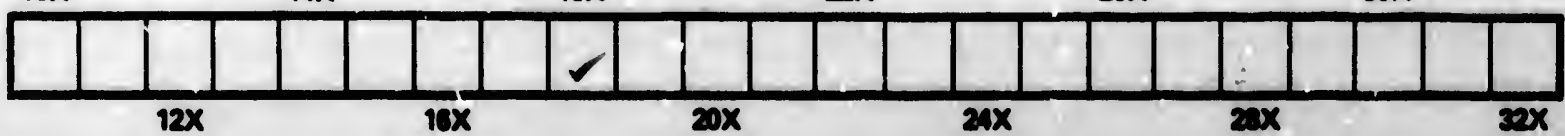


The copy filmed here has been reproduced thanks to the generosity of:

\author{
Librery \\ Agriculture Conada
}

The Images appearing here sre the best quallty possible considering the condition and legibility of the original copy and In keeping with the filming contract specifications.

Origlnal copies in printed paper covers are fllmed beginning with the front cover and ending on the last page with a printed or illustrated impres. sion, or the back cover when appropriate. All other original copies are filmed beginning on the first page with a printed or illustrated impression, and ending on the last page with a printed or lilustrated impression.

The lest recorded frame on each microfiche shall contain the symbol $\rightarrow$ Imeaning "CON. TINUED"), or the symbol $\nabla$ (meaning "END"). whichever applies.

Maps, plates, charts, otc., may be filmed at different reduction ratios. Those too large to be entirely included in one exposure are filmed beginning in the upper laft hand cornor, left to right and top to bottom, as many frames as required. The following diagrams illustrate the mothod:

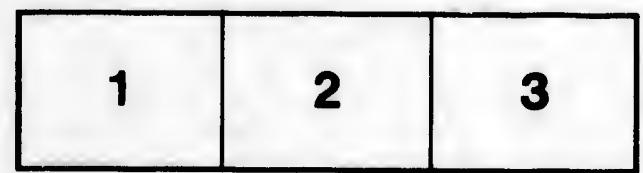

L'exemplaire filmb fut reprodult grâce da la gónórosito de:

\section{Bibliothique \\ Agriculture Canada}

Les Images suivantes ont eto reproduites avec le plus grand sain, compte tenu de la condition ot de la nottets de l'exemplaire films, ot en conformité avec les conditions du contrat de fllmage.

Les exemplaires originaux dont la couverture en papier est imprimbe sont filmbe en commencant par lo premier plat ot en torminant soit par lo dernière page qui comporte une empreinte d'impression ou d'illustration, soit par le second plat, selon le cas. Tous les autres exempiaires originaux sont flimbs en commençent par la première page qui comporte une empreinte d'impression ou d'illustration ot en terminant par la derniore page quil comporte une telle empreinte.

Un des symboles suivants apparaitra sur la derniàre image de chaque microfiche, selon le cas: le symbole $\rightarrow$ signifle "A SUIVRE", le symbole $\nabla$ slgnifie "FIN".

Les cartes, planches, tableaux, etc., peuvent otre filmbes dec taux de róduction difforents. Lorsque lo document est trop grand pour etre reprodult on un seul clichb, II est fllmb pertir de l'angle supúrieur gauche, de gauche droite, ot de haut en bas, on prenant le nombre d'images nócessaire. Les diagrammes suivants illustrent le mothode.
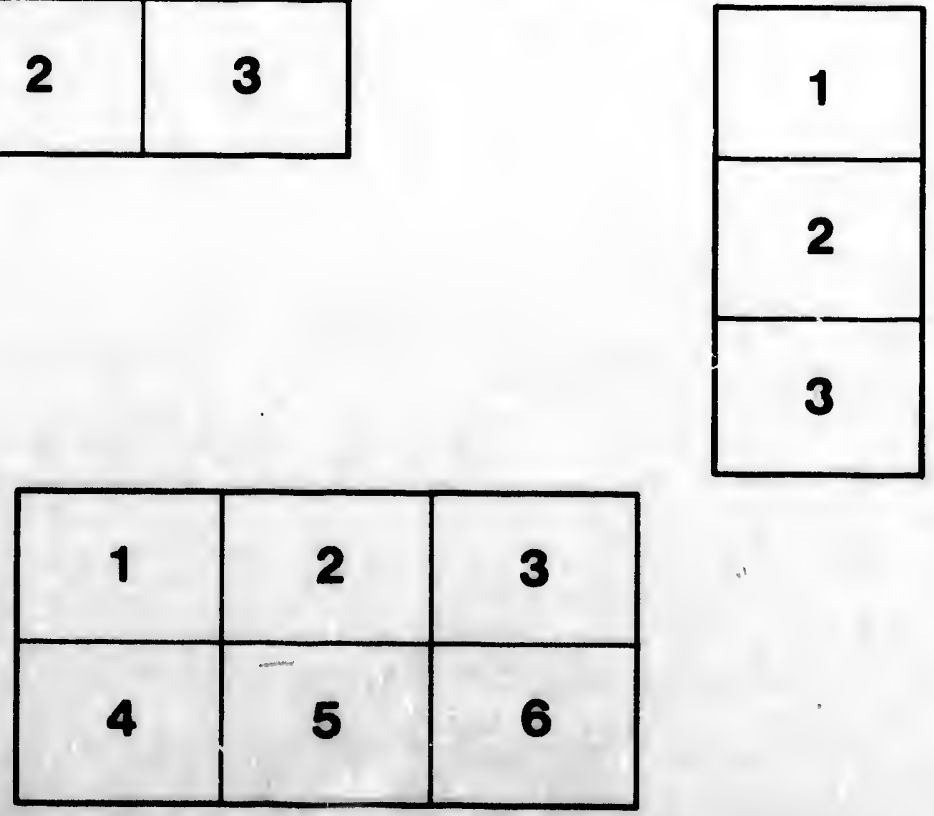


\section{$63 \%$ \\ $43^{3}$}

...23ulletin of 16e Department of Agriculfure,

Practical advice

Practical advice $\longrightarrow$

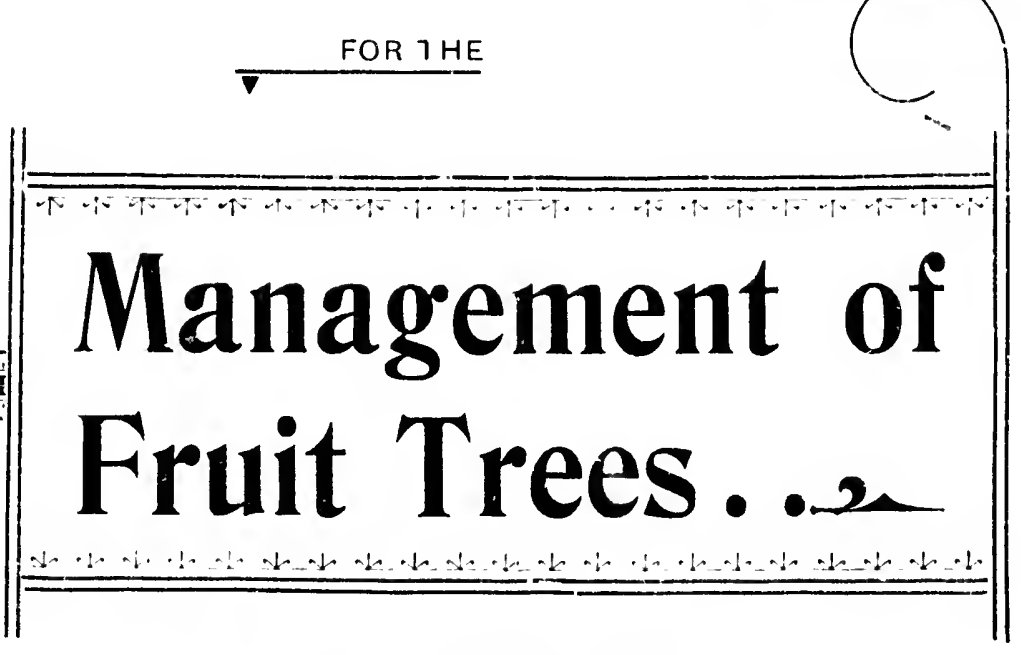

IN THE ORCHARD

1i)

THE REVD. FATHER TRAPPISTES DE NOTRE DAME DU LAC, OKA.

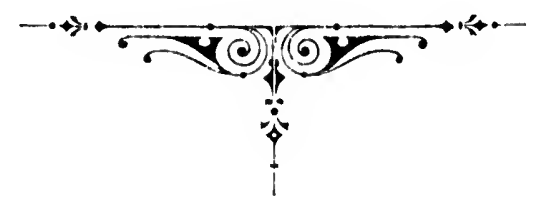

634

QUE円EC

1838

1898

C. 2 
1.

$x^{2}+3+4$

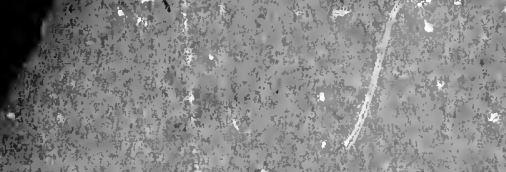

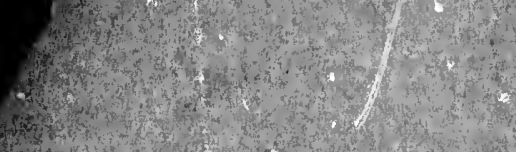

,

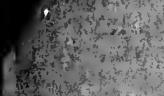
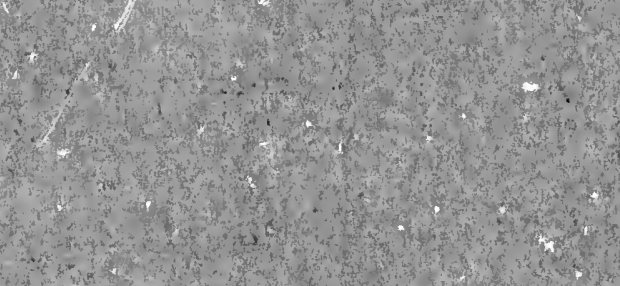

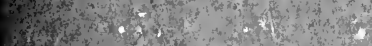

if

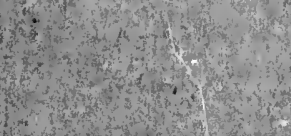

(i.

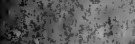

Whis

3

4
4
4
4
4
4
4
4
4

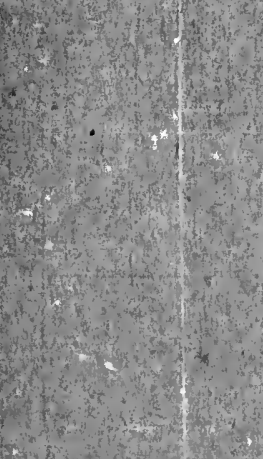

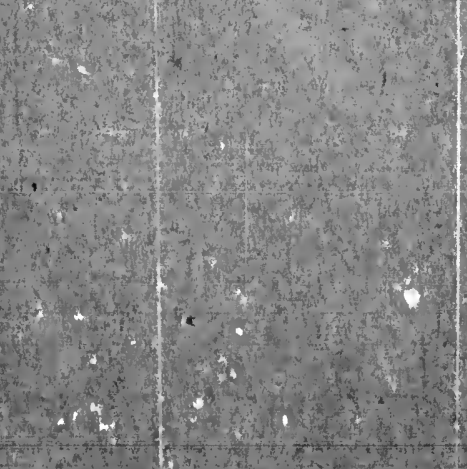

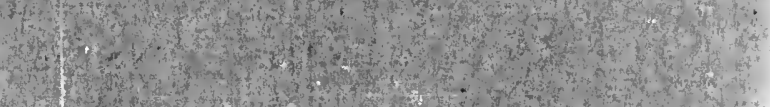

$+4 x+1$

$\bar{i}$

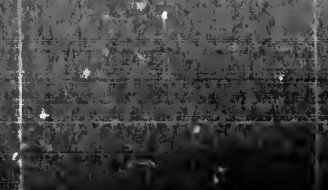

$i=x^{2} y^{2}$ 


\title{
PRACTICAL ADVICE
}

\author{
FOR THE
}

\section{Management of Fruit Trees}

BY TIIE

\author{
REVD TRAPPISTES FATHERS DE NOTRE \\ DAME DU LAC, OKA, P.Q.
}

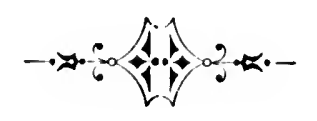

MONTREAL

imprimerie du "Cultivateur," L. J. tarte \& frere, prop. $33 \& 35$ St. Gabriel St. 


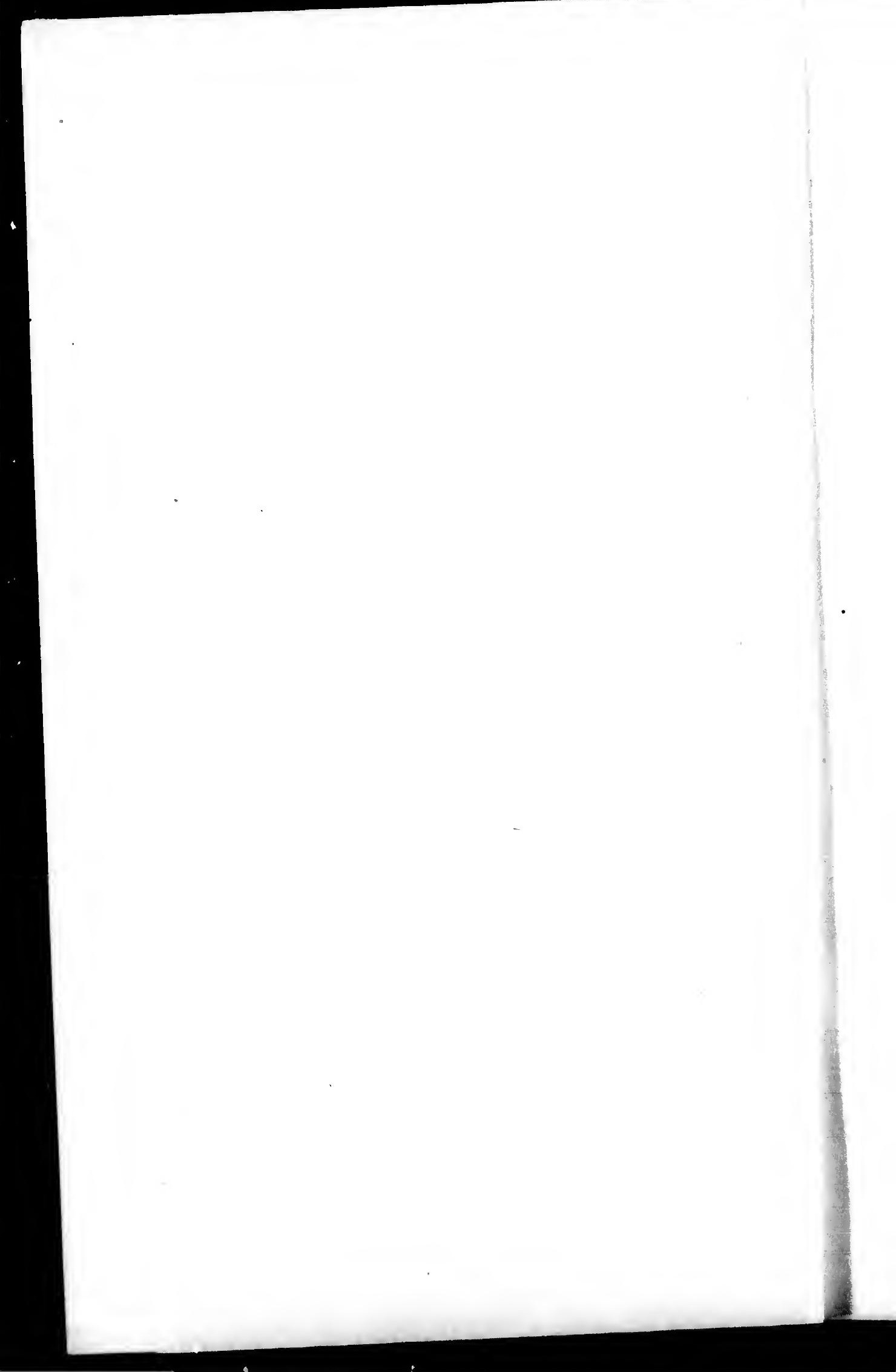




\section{PRACTICAL AIDICE}

FOR THE

\section{Management of Fruit Trees}

IN THE ORCHARD

BY THE, REVD, FATILES TRAPPISTES IE NOTRE

DAME DU LAC, OKA, P. Q.

(Frcm the French).

The Revd Father Trappists, of Oka, in this Province, have loug been known for their practical achierements in fruit culture, and the essay they have written is so plain and useful that the merest tyro, if he would study and adopt the rules it contains faithfully, could scarcely fail of success: I therefore take pleasure in translating and reprinting it for the benefit of my English readers.

\section{Practical advice etc.}

1st Provide good, healthy and vigorous plants.

2nd Prepare the soil properly.

3rd Plant with great care.

th Give intelligent attention to culture subsequently.

5th Gather, pack and preserve the fruit very carefully.

Choice of the plant.-A great part of the disappointment suffered by our farmers is caused by misrepresentation of dishonest agents, who have not the interest of the purchaser sufficiently at heart to give him a 
profitable orchard, nor even to supply him with whatever he wants. These miscarriages have taught some to judge for themselves what are the best varieties for their locality.

The careful nursery man, who makes a specialty of fruit culture and understands the fluctuations of the market, is the proper guide to the purchaser in the choice of varieties; let him apply to a well established and trustworthy house, and follow its advice as to the soris he should plant.

Evils of manting old trees.-Some persons think that there is an adrantage in planting a large tree, and hope to have a crop of fruit sooner. This is a grave error: old trees not ouly yield poor fruit, but become stunted, subject to disease and decay, and in a few years perish for the following reasous, they have a system of large roots which suffer by being cut off in replanting the tree, while those which remain are insufficient to nourish the branches. Again, the bark is hardened and covered with lichens and knots, and becomes the prey and nesting place of insects.

Age of the trees to be planted.-Trees, when planted should be three, or at the most, four years old from the graft, such trees have their roots but comparatively little developed, suffer very little by being transplanted and present all the conditions necessary to insure healthy growth.

Height of trees to plant.-Too low trees should not be planted, generally, for when they grow, culture under them becomes impossible, and when they are fully developed 
they have fruit only at the suminit: the shorter the stem the more vigorous the lower branches, and they will soon produce a crowd of gluttons which must be speedily cut a way: while to do this, much extra work is required, and wounds, which should always be avoided as much as possible, are made. Notwithstanding, there is no doubt but that low trees present some advantages; they are easier to work at, when young, the treatment of disease in them is easier, and they protect each other against high winds. As for trees with too high stems, the difficulty of pruning them, of attending to them in case of disease, and of gathering the fruit with the care which is indispensable, should suffice to proscribe them. Between the two extremes, trees which are four to six feet high in the stem, which have a diameter of 3 to $1 \frac{1}{2}$ inches should be chosen : it would be bad economy to plant trees of any other dimensions with the idea that they are cheaper; in this line of articles, the cheapest are always costly in the long run.

Care to be taken on the arrival of the trees.As soon as received, the package should be opened very cirrefilly and the trees planted immediately, if possible. If all is not ready for planting, they must be put into a trench ; for this purpose a trench must be made sufficiently deep, and wide enough to receive all the roots; place the trees in these trenches one by one, and not in bundles, and see that the roots are covered with earth in such a manner that all shall be in immediate contact with the soil. If the trees are received 
in the autumn, they must be placed in a cellar, sheltered from frost, and the roots buried in fresh sand, neither too dry nor too moist. Nevertheless, we do not ricommend purchasing in the fill; those who have suitable cellars to keep the trees in, may do so, and they will then have the adrantage of having them on hand, and so be able to plant them as soon as the land is dry enough in the spring. It may happen that, in the autumn, the frost may have injured the trees during transportation, in that case, as soon as they are received they must be sheltered from the cold, and a few days must be allowed to elapse before they are unpacked.

II.

Selection and preparation of the soil.-Fruittrees may be cultirated on all kinds of land. Not that they are all equally suitable in a natural state; but they may be made suitable by the industry and intelligence of mar.

Clays, with the addition of materials calculated to render them more friable, such as sand, ashes, etc., are especially fit for orcharding. Trenching, followed by a ploughing, before planting, and thorough drainage, are indispensable requisites in the improvement of such soils. One great advantage of clay soils is that they are not easily exhausted. Apples and plums grown on them are of better flavour than those fruits grown on other soils.

Siliceous silils, those in which sand is the chief feature, are inferior; though when the subsoil is clay, they may be improved by (if possible) ploughing up some of it; thus 
creating a new soil, so to speak, of the very best quality. In the absence of such a subsoil, the cleanings of ditches, heavy dressings of dung, the ploughing-in of green crops, or of any kind of unctuous materials capable of increasing the consistency of the soil, should be practised.

Calcareous soils are those in which lime predominates; they are of a whitish hue, harden quickly and crack under the influence of the sun. (1) The addition to such land of humus and nitrogenous matters, turf and all dark coloured stuff, might benefit it. It is the favourite home of the cherry. (2)

Further on, we will point out, in a few lines devoted to each description of fruit, the soils that are especially favourable to thiir growth.

The thing of all others that fruit-trees dread is excess of moisture. In cold damp soils, the roots rot away. Some sort of drainage in such land is indispensable. In low lands, the easiest mode of draining is, generally, the digging of pretty decp ditches ail round the plantation. (3) In soils of this sort, fruit may be grown successfully if the trees are set out on raised mounds.

We do not advise planting in a low-lying valley subject to much humidity; for fogs and late frosts would hinder the fecundation of the flowers.

(1) Not the chalk-soil of the English Downs.-ED.

(2) See the great cherry-orchards of the lovely district of Canterbury, in Kent.

(3) Drain-pipes would be choked by the roots in a very short time. 
r. Exposure. - An exposure to the South pan, as a rule, be only recommended,for the vine; because, in spring, the sun would be too powerful in its effects on the orchard, since serere fiosts, sometimes occurring at that season, might, when the sap is in circulation, damage the roots and ends of the stems (pieds des tiges).

Select such an exposure as is indicated by the direction of the dominant winds and the lie of the land. No need of enlarging on the damage done to an orchard " when the stormy winds do blow," to excuse impressing on the planter's mind the need of choosi'ig a site protected from the prevailing winds of the locality, $O_{2}$, at the very least, of setting out one or two rows of trees as a wind-break.

Manures.-If trees are to be vigorous, to yield largely, and to belong-lived, they must be well fed. As long as they are young, the dressings that are recessarily given in preparing the land for their reception, may be sulficient to keep them in good condition; but, when they are beginning to bear, and no other crop can be grown on the intervening spaces, a fresh supply of maunre must be afforded. No imperfectly rotted horse, or cow, dung must be allowed to enter the orchard; for, the decomposition of such dung, taking place in the soil, will cause root-rot. Even thoronghly rotted dung has still one defect: its action is not lasting enough. The best of all is liquid manure, on account of its facility oi application. Urine, or the leakage of dung-heaps, diluted with four time its bulk of water, with a pound of sulphate of 
iron to 25 gallons to disinfect it, is a useful application.

Action of the air.-Fine air should be allowed to circulate freely through every part of an orchard, and the soil should be kept constantly pulverised, to allow the air to penetrate as deep as the roots and thereby to strengthen them. The horse or hand-hoe, kept frequently at work, will secure this. It must be remembered that absence of air in the soil? is another cause of root-rot.

Action of light. - Light promotes vegetation and invigorates the tissues. When a tree is ton much in the shade, the only branches it puts forth are long and slender, and never bear fruit. It is light alone that imparts to the fruit flavour and colour; so, it is clear, that the spot shosen for an orchard or fruitgarden should neren be affected by too much shade.

JII.

Many of the drawbacks in fruit-culture are the result of carelesi planting. Antumn planting may succeed in certain cases, but, as a rule, planting in the spring offers the greater chance of success.

Division of the land.-Divide the land so that the long lines shall run in the same direction as the prevailing wind. Show, by means of stakes, the place which each tree is to occupy. There should be 30,feet space between each two trees, and the same 'between the rois. In the intervals between the apple-trees a plum-tree should be planted. The latter will not live so long as the former, but will bear abundant crops of fruit before 
the apple trees are large enough to require all the space. Finally, between each fruit tree currant and gooseberry bushes should be planted, which, having roots that plunge much less deeply into the soil than the apples and plums, occupy space which would otherwise be lost, and produce a crop without interfering at all with the growth of the others. When the orchard is in full bearing, these bushes must be taken away, because they would not yield satisfactorily when over-shadowed. It is easy to calculate what we can put on an acre.

Apple trees..................25 costing $\$ 10.00$ Plum trees.. .... .............20 costing 15.00 Currants and gooseberries..50 costing 10.00 Thus for $\$ 35$ we can furnish an acre.

The approximate profit will be as follows : Apples $\$ 125$

Plums...

Currants and Gooseberries.....

$\frac{15}{\$ 260}$

The place having been marked for each tree or bush, holes must be made of a size pro. portionate to the roots. Supposing the land of an orchard has been trench-ploughed and mellowed, it is not necessary to make the holes very large, only large enough for the roots to have plenty of room so that they can be spread out. The top earth, which is the richest, should be set apart and mixed with well rotted manure. Another heap should be made with the poor earth from the bottom of the hole.

In stony soils, the large stores must be taken out. In heavy land, the holes may be 
made in the autumn, to allow the frost to enter the soil and thus make it more friable. The depth of the hole should be regulated by the length of the roots so that the trees may stand at the same height out of ground as in the nursery. To plant too deep will certainly cause a check, the roots not having air will infallibly perish; while if not planted deep enough, they will be exposed to the direct action of the solar heat and dry up rapidly. Besides, the tree will not stand so firmly in its place. Certain nurserymen, eareful to deliver their plants in good condition, plunge the roots of the young trees and bushes into a puddle of clay, which keeps them fresh during transportation. This layer of clay gires the roots a grey appearance, but it would be a grave error to take the upper line of this colouring as indication of the right depth at which the young tree should be planted.

Planting.-The hole finished, planting should now be proceeded with. The young tree will require a very important operation which consists in re-establishing the equilibrium of growth between the roots and the branches which have been disturbed by the digging up. All the ends of the broken and bruised roots should be cut off clean, with a sharp knife, and the branches of the head shortened in one half. Now, place in the bottom of the hole the soil which has been mixed with manure, and with it form a little mound on which the roots should be spread. The roots should now be covered with the same soil, and the planter should 
shake the tree up and down to cause the good earth to penetrate amongst the roots. Then. press lightly. so that the soil shall adhere to them, and cover cutirely with ihe earth taken from the bottom of the hole - The planting done, the earth should form at the font of the tree a little mound, which will disappear as the earth settles.

Staking.-It is well to prit stakes to the young trees to prevent their being shaken by the wind, the effect of which would be to disturb the roots, prevent them from catching hold of the soil, and hinder their taking. Stakes should be a little longer than the young plant, and should $b_{3}$ driven into the ground at the same time; by driving it in afterwards we run the risk of bruising the roots.

Watering.-If the land is not sufficiently moist, the young tree should be watered immediately after it is planted. On light land which dries up rapidly, cover the earth with long dung to make it retain its humidity. On soils which retain little moisture, l ne the bottom and sides of the hole with sods, watering them to cause them to rot quickly.

In low lands, or lands which are liable to be flooded, plant the trees on the surface. Instead of digging a hole, trace on the earth a circle 6 feet in diameter and cultivate it 8 or 10 inches deep; place the tree on this, and make a mound of good earth mixed with proper manure in order to confine the roots to this level by supplying them with plenty of nourishment. To avoid this being washed away, beat the earth and cover it with sods. 


\section{IV.-Subseruent Care.}

It is not enough to plant trees well to insure success but we must aiso give them constant care, risit them often, and take every precaution against disease. This requires but little time, and when done at the proper season will save many reverses.

First year after planting.-Young trees must not be pruned the first year after planting. Every branch which grows, even on the stem, should be left. It is a good plan to limewash young trees immediately after planting. 'This has the effect of keeping the bark fresh. Dissolve completely some clay in water, then add double the quantity of slaked lime, and enough water to make the mixture about the consistency of batter. Apply it with a brush to all parts of the tree. Towards the month of Augist, wash the bark of the tree with soap-suds; this has the effect of preventing the parts exposed to the air from becoming dry, and it also drives away insects. which infest young and, as yet, tender plants.

At the approach of winter, before the frost has hardened the ground. earth up the tree, to keep away mice, and protect the base against the sun in the spring. If we fear the too great accumulation of snow, and the branches are in danger of being broken by it when it melts, we must fasten them together and tie them to stakes.

Branches which grow along the stem are to be remored, do not cut them off quite even with the trunk, for fear of frost, but leare a little spur a few lines long, to be cut off when spring arrives. 
Second year.-During the month of March, prune the young plants, working in the following manner: keep, for the frame work of the tren, only four branches situated symmetrically round the stem, independent of each other: it would be wrong to allow two or three branches to siart from the same point, they would sooner or later be split off, either by the action of the wind or by the weight of fruit.

The young shoots which are to be preserved, as the starting points of the frame-work, should be shortened in to about half their length to an eye situated on the side next to the prevailing wind; the others should be cut off even with the trunk; the cut should be made at the little swelling which is found at the starting point of each branch, so that it shall slightly run with the slope of the stem. A very sharp pruning knife should be used. The wound should be covered with mastic, to prevent the air from disorganising the tissues.

At the end of June, pinch off the buds which are growing in the interior of the head, leaving the top or the extremities that are destined to prolong the tramework (the leading shoots). This pinching consists in removing with the thumb the herbaceous extremity of the shoot and has the effect of causing the sap to flow into the two leading shoots. If, after this pinching, more buds appear at the end of the pinched shoots, they should be cut off about August.

Third year.-In the month of March, in the third year, cut off, even with trunk, the 
branches pinched the preceding summer and shorten in the leading shoots to half their length, continue the pinching as in the preceding year, and at the close of vegetation the tree should be composed of 16 branches; the head syinmetrically formed, the framework strong and well shaped, with a few fruit-buds already beginning to appear.

Fourth year.-The fruit buds must be reduced in number, so as not to exhaust the tree: from this time the pinching should be discontinued. Pruning is now only neces* sary each spring in the month of March, to reduce the number of twigs and greedy shoots which have pushed into the interior and bring confusion and shade. The sides exposed to the prevailing winds have, generally, a tendency to be failures. If necessary, shorten in the youing shoots to the eyes which are dead on that side. As long as these rules are observed, the trees will always be vigorous and consequently in a condition to yield good crops. The production of fruit causes exhaustion to the trees, but nature helps thern marvellously to repair the loss. It is remarked that trees yield abundant crops only every second year. The year of rest is employed in repairing losses, and in making new fruit-buds for the next year. We cannot complain of this state of things; on the contrary, we should do all we can to assist in restoring these good conditions. The fruit will sell dearer in the scarce years, and the grower will find his profit in it. We should always keep free from grass, etc, a circle round each tree, about three feet from 
the stem, for at least 8 or 10 years after planting.

Thinning the fruit.-When a tree is abundantly covered with fruit it is not well to allow it all to remain. Therefore, thinning should be practised. The young fruits absorb a quantity of the sap without any profit to the tree or to the proprietor, because they are unsaleable. In thinning, try as much as possible to leave the fruit growing on the larger branches, those which are left will be the largest and best flavored. However, when the trees are old and spreading, thinning is hardly practicable, and although it is just as useful then, it should be abandoved, especially by those who have large orchards. In gathering time, and in the storage, the fruit should be sorted. if it is desired to sell only the best of the crop.

Replacing dead and worthless trees.-It is always prudent to replace a dead or infirm tree by one in better condition. Remove as much as possible of the roots of the tree taken away.

Diseases.-Fruit trees are the prey of a legion of insects and fungi, against which never ceasing struggles must be made. The treatment of the diseases is indicated in the few lines deroted to each species.

It seems costly and difficult to apply these remedies, but it is a trifle if we take care to prevent the malady by treating it at the proper time. We strongly advise our farmers to mutually protect themselves against the in rasion of hurtful insects and fungi. Who can estimate the damage cansed to his 
neighbours, and sometimes to a whole parish, by one negligent farmer?

und-

V.

Gathering Fruit-Packing-The Fruit-room

Gathering the fruit.-It is very difficult to indicate any exact time for gathering the fruit; it raries with the year, the site of the Orchard, and the rariety; it is essentially a business which requires personal observation.

Whatever the rature of the fruit it must be harvested in dry, cloudless weather. Summer apples should be gathered a day or two before their complete maturity, and disposed of as soon as gathered, as they will then stand a journey better than if quite ripe. Autumn and winter apples keep all the better according to the longer tirne they take to ripen. They should be gathered before they are quite ripe. Plums and cherries should be quite ripe when gathered. The tree should never be shaken to make the fruit fall; it would be bruised, rendered unsaleable, and would not keep long. Fruit should always be picked by hand; never climb the tree, as that would bruise the bark and break the branches; but use a step-ladder sufficient loug to reach the highest part of the tree. The fruit should be placed carefully in bas. kets, and taken to the packing-room in good condition.

Manner of keeping fruit. - The fruit-room should be so constructed that cold cannot enter ; rather dark, free from too much moisture, and yet not too dry. The fruit should be 
placed on shelves with the stalks downwards, and must not touch each other ; they should be placed in their separate varieties, and each sort labeled. During the first four days they should be wiped dry, very lightly, with a soft cloth.

Those who have no fruit-room in their houses can keep fruit yery well in th: follow. ing manner. A perfectlv clean barrel must be provided, and the bottom corered with a layer of fine sand mixed with slaked lime; on this place a row of apples, with the stalks upwards, and not touching each other, fill the spaces between with the same sand and lime and completely cover the first layer, lay a second row of apples on this with the stalks downwards; next, fill in with the sand and lime, and so on, until the barrel is full. covering all with sand; then close the barrel, making it all tight. As fruit is taken out for use, the last layer should always be kept covered.

If, for want of care, apples are frozen, they may be restored thus: fill a large vessel with moderately cold water, put the apples in, and place it in a warmish room. Shortly afterwards, there will be a coat of ice formed round the fruit; when this is taken off, they will be found to have regained their original flavour.

Facking fruit. - Generally speaking, it is better to pack fruit for market in compartment boxes such as are used for eggs; each fruit being wrapped in thin paper, and placed in its own compartment. Apples must thus be of uniform size, and will not knock 
own-

they

eties, four hitly,

their llow:

must ith a ime ; talks , fill and , lay the sand full. arrel, $t$ for kept they vith and ftermed hey inal

it is artach and iust ock

against each other during a journey. Boxes of 16 dozen of Wealthy have realized 70c. a box, off the tree.

Fruit is usually taken to the local markets in barrels and packing begum at the head; to close the barrel a very si::-ple press, well known in the country, is used. The name of the variety is marked on the cover. Beside selling the fruit, making cider and arying are good means of utilising surplus fruit. We engage that, if the farmer adopt these preceeding plans, he will, we are sure, find the key to success.

Apple-trees. - The apple-tree rejoices itself in a dry, rather than in a moist soil, no matter how gravelly. To yield well, and long maintain its vigour, it requires a deep, rich, and mellow soil. It is the fruit-tree of the future for the Province of Quebec, and by choosing pruper varieties, apples can be planted as far as the regions of the north. Apples are a delicious fruit, and bring to the family comfort and welfare; there is no proprietor who may not have a rew apple-trees on his land, and thus have at all seasons of the year, fruit of first quality, sound and wholesome.

The following rarieties having been proved to be the best for this country, should be planted in preference to others.

\section{Summer apples.}

Yellow transparent. - Fruit pale yellow, medium size, and of excellent quality ; flesh, white turning to pale yellow at complete maturity: the tree is vigorous and an early 
and abundant bearer ; ripens at the end of August.

Strawberry of Monlveal. - Fruit medium size, red all over the surfiase, except side away from the sun where it is a bright golden yollow; flavor aromatic and agreable. T'ree vigorous and hardy; ripens at the end of August.

Red Astrachan.-Fruit about medium size, color bright red with dark dots. A magnificent apple of first quality. Tree vigorous, but a little late; succeeds well in the north, ripens at the beginning of Srptember.

Tetofsky. - Fruit a little above medinm, red and golden yellow, flesh white, juicy and a little acid, with an agreable perfume. Tree vigorous and hardy, bearing early and abundantly; ripens in mid-September.

\section{Autumn apples}

Duchess of Oldenlurg.-Friit about medium, red striped and barred with yellow on the side opposite to the sun, flesh juicy, slightly acid; tree vigorous and very hardy, bears early and abundantly. It is the apple for the neighbourhood of Quebec; ripens at the end of September and the beginning of October. This is a grand apple both for the local market and exportation.

Alexander.-Fruit very large, red all ovtr, flesh white, a little acid, flavor agreeable. Tree vigorous and hardy, ripens from October to December.

Chenango's Strawberry.-Fruit medium size, red and pale yellow, flesh white, juicy and very tender. Tree vigorous.

Maiden's blush.-Fruit medium, pale yellow 
slightly colored on the side opposite to the sun. Succeeds well every where and should be planted.

Red Beitigheimer.-A German variety, rare and highly esteemed, skin pale, but a deep red in the sun, flesh white, a little acid, llavor agreeable. The tree is vigorous and hardy.

Fameuse.-The most popular apple in the vicinity of Montreal, fruit medium, red and pale green, flesh white, tree vigorous and hardy. The apple spots easily and should be treated with Bordeaux mixture.

IIras.-Fruit medium, red and pale yellow, flesh white, tender and juicy, a little acid. Tree exceedingly vigorous and hardy, ripens from September to November.

\section{Winter apples}

Wealthy.-i'ruit abont medium size, brilliant red, principally on the side exposed to the sun, sometimes a little greenish in the shade, it will keep until February, and is the fruit."par excellence" for exportation, The tree is vigorous, hardy, and produces abindantly.

Canada Baldwin. - Fruit medium large, skin smooth, yellow, striped with carmine and crimson, sprinkled with large dots, flesh white, frequently tinted with deep rose, firm, juicy and sub-acid, having a slightly astringent taste, peculiar but not disagreeable. Season mid-winter and later. Tree vigorous and hardy, succeeds weli in clay loams.

Ben Davis.-Fruit large, round, sometirnes a little conical, pale yellow, strongly marked with red in the sun, flesh, white, juicy, and 
sub-acid, qnality axidium. Its specialty of keeping until the spring, and its beautiful appearance make it a favourite in the English market where it fetches a high price. The tree is vigorous and very hardy.

Golden Russet.-Fruit medium, of a beautiful color, golden yellow with the skin sometimes reddish brown, juicy, and of an exquisite fiavor, will keep until spring. Tree vigorous, hardy, and prolific, ripens from November to April.

Longfleld.-A Russian varicty very muci. to be recommended, fruit small, yellow and red, of an agreable flavor, and keeps well until March. The tree is vigorous and hardy.

Mann.-Fruit about medium size, green, sprinkled witb black dots when gathered, but changing to deep yellow when perfectly ripe ; its exquisite flavor and perfume make it a great favorite. The tree is vigorous and hardy; keeps until April.

Macintosh Red. - About medium size, round, slightly flattened, deep red all over; flesh white, juicy. flavor and perfume exquisite. Tree vigorous, hardy and an abundant bearer. Keeps from November to February.

Northern Spy - Fruit large, slighly conical in form; pale yellow streaked with crimson on the side exposed to the sun, ripens in January; it succeeds best in the neighbour. hood of Montreal and towards the south.

Pemaukee.- In size medium, ribbed and slightly conical in shape ; skin, a clear yellow, perfume exquisite, these qualities make it a first-class fruit for exportation. The tree is 
vigorous and succeeds everywhere. It begins to bear late, but gives excellent crops.

Pomme grise. - Fruit small, grayish red, flesh tender and aromatic. The tree is vigorous, but it only succeeds. well in the South and West.

Quebec Winter.-Fruit medium size, color yellow, with stains of red next the sun; flavor acreable; this variety is highly recommended. Tree rigorous and hardy.

Roxbury Russet. - In size about medium ; dark-green sprinkled witn strins of a yellowish brown, flesh greenish white, not vary juicy, flavor agreeable. Tree vigorous.

Salome. - Fruit average size, round and conical; yellow with reddish tint next the sun; flesh, pale yellow, juicy and with a dleasant flavor. The fruit will keep easily until June. Tree vigorous and hardy.

Scott's Winter. - Fruit in size medium; colour varies from bright red to reddis h brown; flesh, pale yellow, slightly tinted with red near the skin, its flavour and perfume render it an apple of the first quality; the tree is very vigorous and rery hardy, bears abundantly, aild the fruit keeps till Jume.

Smith's cider.-Fruit larger than medium, yellow flushed with red; flesh tender, juicy and rich, ripens September to March. Tree vigorous.

Babbit.-Fruit very İarge, almost entirely red; flesh juicy und rich. October to spring. Tree hardy and vigorous.

Wolf River.-Fruit very large, pale green with sometimes a little crimson; flesh, white 
tender, and juicy; January and February. Tree hardy and vigorous.

John Ruchardson. - Fruit very large, red all over but sometimes greenish in the shade. Tree hardy and rigorous.

Reinette $d u$ Canada.-Fruit very large, a dull yellow; flesh white, firm, rich and of the first quality, November to March. Tree vigorous and hardy.

\section{Crabs}

Hyslop's. - A crab highly esteemed for its sizo, brilliant color and keeping qualities: the tree is hardy, vigorous and a very abundant bearer.

Transcendent. - Fruit medium, red and yellow. The tree is hardy, vigorous and yields abundant crops.

Whitney's Seeding No. 2.-Very large, an excellent dessert fruit; still better when cooked, and makes capital cider. The tree is beautiful in shape, and produces abundantly.

Early Strawberry - A variety highly recommended, hardy and vigorous.

\section{Drying Apples}

The drying of fruit is an industry taken up to a considerable extent during the last few years, and especially in the United States. Co-operative drying houses are established to which the orchardist can take his truit, as the dairy man takes his milk to the creamery; but any one can evaporate his own fruit by means of a special apparatus which is cheap and easily obtained. The preparation of apples for drying in an evaporator consists in peeling them, taking out the core, and cutting them in slices; this is rapidly done by 
ingenious machinery that can be bronght for a small sum.

It is now the custom to submit peeled apples, before or after being sliced, to the fumes of sulphur. This operation is called bleaching, and gives a better appearance to the fruit causing it to retain its colour. The sulphar is placed in a vessel over a fire and the vapor passes through the fruit, which is placed in trays above, the fumes escaping by the top; the time necessary for this operation is about 2.) minutes. After the bleaching, the fruit is placed on wire trays, fitted to the inside of the drying chamber of the evaporator, where it remains until sufficiently dry, which takes from $2 \frac{1}{2}$ to 4 hours. The fruit must be remored before it becomes brittle, while it is still tender though a little tough.

For the drying of apples there will be required: 1st, portable evaporators, varying in capacity from 5 to 150 bushels a day, :nd, evaporating ovens that are not costly.

Packing dried fruit. - The fruit nust not be packed till 24 hours alter drying. It is then put into paper-lined boxes holding from 2: to 50 , or $75 \mathrm{lbs}$. A box for $50 \mathrm{lbs}$, should be $12 \times 12 \times 2+$ inches.

Evaporated apples should be packed in the same manner as the green fruit, that is to say, beginning at the top of the case; nail on the cover, and then turn the case upsid" down, then place a sheet of paper in the case. and arrange the layers of fruit regularly in lines; letting each layer corner tine preceding one. When the case is full, nail the 
bottom, brand it and it will be ready for market.

Varieties to evaporate.-Summer apples are not fit for the purpose.

The following table gives the best winter varieties for evaporating :

1 Northern Spy 50 los will give when ciry 9

2 Golden Russet "6 " " 9

3 Ben Davis

4 Pewankee

5 Pomme Grise " "

6 Canada Baldwin “

7 Fameuse "6

8 Gedeon

9 Haas

10 Longfield

11 Scott's Winter "

12 Wealthy

66

6

66

"6

66

66

“

“6 9

" 8.7

" 8.2

" 7.13

6 6.14

66 6.4

$66 \quad 6.4$

6 5.15

6 5.5

(Extract from report of Experimental farm, Ottawa.)

\section{Making Cider}

The culture of apples for cider is destined to increase enormously in the Province of Quebec ; and for many reasnns : 1st The soil is eminently suited to their culture, and it is proved that the Canadian apple is superior for the purpose to the Norman apple. 2nd. Without doubt, cider is a wholesome and agreeable drink, and its manufacturo should be more general in this country

To make really good cider the apples must be quite ripe. (1)

A very simple and cheap way of making good cider consists in having three hogsheads, open at one end. Place in one, $100 \mathrm{lbs}$ of apples, cut into small pieces, on these pour $3 \frac{1}{2}$ gallons of water for the first time. To prevent the fruit from floating, place in the hogshead, on the surface of the fruit and

(1) And shonld be piled in heaps for two or three weeks before crushing. 
water, a cover of boards, held together by a transverse board. After 12 hours of immersion, draw off $3 \frac{1}{2}$ gallons of water, by means of a faucet placed at the bottom of the barrel, and pour into this hogshead which we will

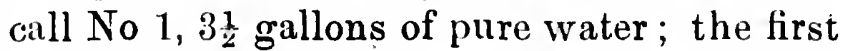
juice taken from it pour into No 2 hogshead, having previously placed in it another 100 lbs of crushed apples. After another 12 hours of immersion, draw.off the juice from the two hogsheads ; the juice of No 2 pour into No 3, anuther 100 lbs of apples having been previously added, then the juice of No 1 is put into No 2 and $3 \frac{1}{2}$ gallons more of pure water is poured into No 1 , which is the last. At the end of 12 hours the same work is repeated, the juice No 3 is collected and the juice of the other two is added successively. After they have passed No 3, the crushed apples are thrown away. There should now be about 12 gallons of apple juice, and when this is fermented it makes a verv good family cider.

The juice should be placed in a barrel, left open at the bung-hole. Before long, a bub. bling sound will be heard, produced by the liberation of carbonic acid. This working usually lasts three or four weeks. The cider should be kept in a temperature of not less than $46^{\circ}$, and no sudden variations of temperature should be allowed in the fermenting room.

Care must be taken that the cask be kept constantly filled up, so as to allow the foreign matter, brought to the surface by the fermentation, to run off. The addition of sugar to 
the juice increases the alcohol, when, at the same time, tannin and tartaric acid are added. For the quantity of juice above mentioned, sugar 1 lb 12 ounces, 2 grammes tannin, and $\frac{1}{3}$ ounce of tartaric acid should be added for each degree of alcohol desired.

When fermentation ceases cork up tightly, and to be sure that no accident happens it is well to bore a gimblet hole at the side of the bung, in which place a straw for a few days; finally, make it air-tight-with a wooden plug.

\section{Diseases of the apple.}

Slrangling of the trunk.--To remedy this, make three or four longitudinal incisions in the trunk, penetrating into the inner bark or alburnum.

Canker.-Canker is a point on the road to disorganisation in the midst of a living tissue. It is said to be open when the central portion, in full disorganisation, is surrounded by a round swelling of healthy tissue, and it is said to be close when the lips of the swelling are greatly developed and have a tendency to come together. Apples planted in moist soils are often affected with this disease, and it also develops when the circulation of the sap is suddenly checked by cutting off branches when it is in full activity, in April and May.

To avoid canker, we unust

1st. not make rents or scratches, but only clean cuts.

2nd. Not plant apple trees in too moist places.

To cure canker : with a very sharp knife, 
at the added. ationed, in, and ded for

tightly, ens it is e of the w days; wooden

dy this, sions in er bark

road to living central ounded , and it of the have a planted ith this the cirked by ali acti-

ul only

moist

knife, cut away the damaged tissue, so as to remove the germs of decay, then rub the clean wounds with sorrel; when the wound is dry, cover it with grafting wax.

Rust. - The stems and branches which present cavities resulting from destruction of the tissues, are said to be rusted. To stop the ravages of the disease and preserve the infected parts, the coming of the corrupting germs and the elements necassary for their derelopement must be arrested. For inis purpose, the walls of the cavity must be sheltered from the air and moisture by filling them with mortar and excluding the air by covering the opening with grafting wax.

Mosses and lichens.-Scrape the old bark with a scraper to take off the mosses and lichens and cover the cleansed parts with milk of lime.

Caterpillars. - In March, while the trees are still leafless, take off all the rings of caterpillar's eggs round the branches. Destroy their nest as fast as they appear, and crush the caterpillars, smear a portion of the stem with linseed or olive oil, to prevent their ascent.

Green grub or plant louse. - These feed on the green matter contained in the leaves and the soft extremities of the young shoots: coal-oil emulsion will kill them.

Dissolve $\frac{1}{2} \mathrm{lb}$. strong soap in one gallon of boiling water; when the soap is thoroughly dissolved pour in 2 gallons of coal-oil, stir or churn and thoroughly mix until the mixture has a creaming appearence; then 
add nine times its volume of water, that is to say, 27 gallons. Apply with a sprayer when the trees are young, and later, by means of a watering barrel mounted on wheels.

Be careful that the emulsion is properly made; one drop of pure coal, oil will immediately burn the part of the tree on which it falls.

Woolly grub.-This insect is reddish brown covered with white down, and does great injury to the apple-tree. The waxy down with which it is covered protects it from most insecticides.

When a young tree has its stem and branches corered with cankerous knots, it is often better to eradicate it planting a good one in its place, than to treat it with insecticides. Insecticides should dissolve the cotonny matter that covers the grub, and kill it, without destroying the tissues of the tree. Alcohol, raw fish-oil, phenic acid, with much water, urine, tobacco juice with plenty of water, alcohol and petroleum, are the insecticides recommended, and may be used at all times successfully; most of these should be used only before the developement of the leaves.

In the spring, before the opening of the flowers, spray the entire tree, particularly any part affected, with a mixture $\frac{2}{3}$ water and $\frac{1}{3}$ tobacco juice, with a weak addition of alcohol.

The Borer. - Sometimes a tree perishes suddenly without any apparent cause; this is mostly due to this insect, which being furuished with very strong mandibles, digs 
$t$ is to when ins of perly mmeich it

rown great lown from

and it is good sectiton$11 \mathrm{it}$, tree. with with are y be hese nent

the arly ater a of hes this ing ligs or bores into the heart of the tree and makes large galleries which ramify in great numbers. The base of the trees should be carefully inspected in August and washed with soft soap. If the worm has already done its work, it should be extracted with a needle or small piece of wire, the hole closed up with mortar or cement, and sprinkled orer with phenic water.

Bark louse.-These are always to be found on trees which are in bad condition, from neglect, worn out or decrepid from age. The remedy is grood culture, and proper pruning to stimulate vegetation and give the tree back its lost vigor. Then, the bark should be scraped and washed with a couch grass whisk, dipped in soapy water.

A good preventive of this kind of insects is to apply lime to the tree in the autumn.

Apple-gnawing worm.-The ravages of this insect can be prevented by the application of Paris green when the fruit is begining to be formed; and a second time, when it is partly grown. Nature has given us, in the birds, powerful auxiliaries in the battle with the legions of insects which infest our orchards. We must be careful not to destroy the birds completely, and count for little the few cherries they may eat or the apples they may damage, in comparison with the millions of insects which they annua!ly destroy (1).

Spot or scab. - We often see the leaves and the extremities of the young shoots being

1. But utterly exterminate that predaceous scoundrel, the sparrow. 
struck suddenly yellow, next, the base of the branch becomes yellow in its turn, and then the entire branch. Jf we observe closely, we shall see that the wood is blackened and the bark loose; and if we wait too long, tiae whole tree will become the prey of this terrible fungus, called spot or scab. It multiplies with prodigious rapidity, and when an orchard is infected, the surrounding orchards soon suffer in the same way.

If care were taken to treat the trees with Bordeaux mixture in the spring, when the buds are opening; a second time, when the leaves are developed; and a third time, when the year's shoots have g own long, we could prevent the plague. But the mischief is often only perceived when it is too late. In that case, the affected branches must be cut off to the place which is perfectly healthy and exempt from all black stain, neither should we hesitate to grub up a tree to preserve the others. The branches cut off should be burnt; to leave them lying on the ground favours the propagation of the spores of the fungus. When all the diseased parts are removed, we may make another application of the Bordeaux mixture, which is thus composed :

6 lbs. sulphate of copper

4 " lime

22 gallons of water.

To prepare this, dissolve the copper sulphate in 16 gallons water, slake the lime in 6 gallons of water. and when this is cool, pour it slowly into the copper solution, mixing it thoroughly. Paris-green may be addep 
to the Bordenux mixture, which will make it all insecticide as well.

Apple spot. -This attacks certain rarieties, particularly the Fameuse, Macintosh Red, etc. It is caused by a microscopic fungus and Bordeaux mixture will combat it. Apply first when the fruit is about the size of a nut, a second time, when about $\frac{1}{3}$ its growth, and a third time when $\mathrm{g}$ its full size.

\section{The Pear}

The pear-tree demands deeper and dryer land than the apple. It succeeds well around Mantreal and in the southern counties. If planted on warm sites and sheltered from North and North-West winds which injuro the blossoms in the spring, good crops may be obtained. At Montreal, pears yield well.

The culture of the pear may be adrantageously pursued in the above situations; not so as to rival the fruit of Ontario, but for domestic use. The best rarieties are the following :

Clapp's Favorile.-Fruit large, citron-yellow, flesh delicate, granulated, rich and melting, tree vigorous, but it needs a warm place.

Flemish Beauty. - Fruit large, brownish yellow, with red spots, rich, juicy aud exquisite flaror, tree rigorous and much more hardy than the preceding.

The pear-tree is attacked by different insects and fungi, the characters of which are identical with those which attack the appletree and which may be treated with tho same remedies. 


\section{The Cherry}

The cherry fears moisture rather than drought. It likes light soil of medium consistency, sandy and mixed with a little chalk or lime, it does not thrive well on clay soils. The best varieties are the following:

Early Richmond.-A well known cherry, dark recl, medium size, flesh juicy and acid ; tree vigorous, and can be grown successfully anywhere.

Empress Eugenie.-Fruit large, deep red, flesh juicy and tender; a little acid, vigorous and hardy.

English Morella.-Fruit large, deep red (1),

(1) Almost black, when really ripe- $-A$. R. J. F.

tender and juicy, a little acid, very early, tree vigcrous and very hardy.

Large Montmorency. - Tree intensely vigorous and very hardy, yields abundantly, fruit very large, flesh fine and delicate, ripens about a week after the Early Richmond.

Louis-Philippe. - Fruit large, tender and juicy, slightly acid, comes about the end of July. The tree is vigorous and hardy.

The disease most injurious to the cherry is the gum, that is, the exudation of the sap, causer by clumsy pruning. When not too severely attacked, the tree can be restored by cutting off the diseased branch as far as a young shoot, which will probably send out healthy sprouts.

The pruning of the cherry tree is reduced to the thining out of the centre so as to admit the air and light. Large cuts should not be made when the sap is in full flow, i.e., in April and May. 


\section{The Plum}

The soils most farourable to the plum are heary and cool. The trees not being tap: rooted do not need a very deep fertile hed. It does not thrive in sandy soil.

The following are the rarieties best adapted to our climate.

Bradshav.-Fruit large, purplish red with stains of blue; tree vigorous and very productive.

De Soto.-Fruit medium, light red, flesh juicy, sweet, and of good quality, tree excessively vigorous, hardy, and prolific.

Lombard.---Fruit riolet red, flesh yellow, juicy, and pleasant to the palate; tree rery vigorous, hardy and prolific.

Niıgara.-Fruit very large, deep blue; tree very hardy and a good bearer.

Damsom.-Fruit light purple, tree vigorous and a good bearer. (Damascene.)

Diseases of the plum.-The plum has two great enemies, which war desperately with it; namely the Black Knot and the Curculio The first is a fungus, and the second an in sect. With care and intelligent culture these two plagues may be subdued, or at least their ravages considerably restrained. As soon as it is seen that the fruit is affected. they must be destroyed. In the first place, shake the tree well; the fruit affected will drop into a cloth placed at the foot of the tree and then must be burnt.

As a remedy against the Black Knot, it is recommended to use a paste composed of coal oil and turpentine; but what is still better is to cut off the affected branches and 
burn them, nor should we hesitate to destroy the whole tree, if necessary.

\section{The Vine}

The vine does not like too rich soil; it yields better in soils which are poor, light, but perfectly mellow, well drained, and entirely tree from moisture. A southern exposure is indispensable, especially for varieties which ripen late. To remedy the possible injury arising from too much sunshine in the spring, as well as from the extreme cold of winter, the stem, which is to be pruned as indicated, must be buried in the ground. Plant the vine in the following way: make a hole two feet every way, so that one of the sides of the hole in the direction of the row of vines is sloping, so as to allow the vine to be laid down for the winter.

At the bottom of the hole place some thoroughly rotted manure, and cover it with some good earth, in which the roots of the young plant are to grow. Bury the vines in the ordinary manner, so that the stem may lean upon the inclined part of the hole, with only one eye out of the ground. Tread it in lightly. Vines should be planted in lines running from East to West, so that the mid-day sun may exercise its free influence upon the grapes. To winter the vines, we must detach them from the stakes, to which they are fastened in the summer, and lay them down, covering them with a mound of earth of sufficient thickness; care must be taken that this is not taken from the foot of the vine so as to lay bare the roots. The pruning of the vine is thus done; the year 
of planting it pushes out several branches, every one of which must be kept. In the autumn, the branch which has grown most vigorously, and on which the eyes are the closest together, must be kept, the others are taken off, the one that is kept must be cut back to half its length. The second year, after unearthing the vine, we fix it, by means of osier bands, to a trellis inclined in the same direction as the rine.

The eyes of the long shoot now begin to develop; now, the eyes of the vine are double. The first that are developed give birth to premature buds, which will produce no fruit. These must be pinched to about 7 or 8 leaves. The shoot at the extremity is stopped for the purpose of favoring the developement of a second eye, the only one capable of giving a long vigorous leading shoot with the eyes sufficiently close together. In the autumn, the premature shoots are cut off, the leading shoot is shortened in to one-half its length and the vine buried. The next spring, care must be taken in taking up the vines, not to injure the eyes. Place the vines on the trellis as in the year preceding. From each eye a vigorous fruiting branch will be produced, the eyes of which are very near together, and bear a bunch of grapes near the four or five first leaves. The leading shoot is to be treated as in the preceding year. Each eye of the fruiting shoot brings a premature shoot which should be pinched to the 7 th or 8 th leaf.

When the berries are wel! formed, cut the fruiting shoot at the second leaf above the 
last bunch, to force the sap into the berry, and thus increase its growth and hasten its maturity. After the gathering of the grapes, the fruiting shoot: should be pruned to two eyes from their connection with their parent stem and the leading shoot to three or four eyes. The vine stem will be found to be bristling with a series of spurs, each provided with two good eyes which will produce the year following two good fruiting branches; these branches are treated as abore:

In the autumn, cut off the shoot on the branch the nearest to the base, and the branch above the two eyes. Every year we provide spurs even having two good eyes.

The best varieties of the grape are ino following :

Bacchus.-Black, small and compact bunch, good for wine or for cooking (1).

Champion.-Black, very early, recommended on this account,good for wine and the table.

Concord.-Bunch large, black. yields abundantly, and ripens early enough to be gathered before frost; good for wine and the table.

Delaware.-Bunch small but compact, fruit red and of a delicious flavor; good for the table.

Duchess. - White, of excellent quality, yielding largely, bunch $\mathrm{m}$ 2dium, a dessertgrape.

Moore's Early,-Black, vine vigorous and hardy, fruit large and ripens earlier than the Concord. It resists the mildew well and is good for wine and for dessert.

(1) Office is the kitchen; cuisine is what is marle in the kitchen. 
Moger.-Red, resembles the Delaware, but ripens earlier, the fruit is delicious; a choice grape for the table.

Niagara.-White. vine hardy and produclive, larger than the Concord, ripens nearly at the same time.

Vergennes.-Bright red: fruit will kien part of the winter; flesh tencter and delicate, excellent for the table.

Roger's No. 9.-Large red ; produces abundantly ; ripens early; excellent for wine or for dessert. (1)

To preserve grapes, proceed in the following manner: Take a wooden box and line the inside with a sheet of zinc so that it will hold water, make a cover with holes in it large enough to allow a shoot of the vine to pass; instead of cutting the grapes by bunches, cut pieces of the branch containing two bunches. Fill the box with water, in which is put a little sulphate of iron to prevent putrefaction. The extremity of the rods on which are the bunches are placed in this. Grapes thus preserved will keep until spring. if placed in an apartment where there is very little light and no frost.

Diseases.-Good culture and the soil kept constantly clean and well worked, contribute largely to prevent diseases. Nevertheless, they will appear. The principal is tie mildew which attacks fruit and leaves. For this, use Bordeaux mixture when the buds are expanding, afterwards use ammoniacal copper carbonate: dissolve $4 \mathrm{oz}$. of carbonate

(1) It should be remembereo that dessert, in England, is composed of ices, fruit, and cakes, alone. 
of copper in two quarts of liquid ammonia, and when required for use, dilute with 30 gallons of water. It may be reduced to any quantity, if these proportions are observed.

\section{The Strawberry}

The strawberry is an excellent fruit, very wholesome, and, with a little care, a crop may be had all the season.

Strawberries may be divided into two classes : the large fruited, producing only in the spring, and the "four seasons," giving small frnit, highly scented, during the whole summer.

A mong the large fruited, the most to be recommended are:

Jumbo. - Large, red and white, of exquisite flavor and remarkably early.

Wtison's Albany. - Not quite so large as the preceding, brighter red and more productive, flesh, more highly scented, and more delicate in flavor.

Duc de Montmorency.-A new variety, which prcduces abundantly and is of the greatest hardiness.

Strawberries of the second class preserve the generic name of "Four seasons"; the fruit varies but very little.

The strawherry requires a mellow soil of medium consistency, manured the preceding year; it dislikes fresh dung and needs constant moisture; consequently, care should be taken to plant strawberries, on beds so arranged that the rain will not easiiy run off: The runners are the plague of the strawberry; they exhaust the mother plant, and injure the quantity and quality 
of the fruit. They should be cut off on all strawberry plants, as soon as they appear, whether small or large fruited.

Atter bearing for three years, the plants produce very little, and it is better to make a new plantation, renewing a third part each year.

Preparation of the soil.-We have seen that the strawberry plant does not like fresh manure; consequently, the soil intended for strawberry culture should receive 45 bushels of wood ashes to the acre mixed with pigeon or poultry dung; trench the land two spits deep (1) and harrow so as to level the land and mir the manure thoroughly with thesoil.

Planting.-Trace lines the length of the ridge, 1 to $1 \frac{1}{2}$ foot apart if in a garden, and 3 feet if in a field, so that a horse hoe can pass between the rows. Plant strawberries as you would vegetables, the space between each plant in the row should be 18 inches. Immediately after planting, give a good watering if it seems necessary. The subsequent work required is hoeing and the destruction of the runners.

Planting in the month of August always succeeds well. The advantage of planting at that time is that a year is gained in the production of fruit.

At the beginning of winter (2) cover the plantation of strawberries with straw or dead leaves. It is well nlso to scatter green branches over the heds to assist in the accumulation of snow.

(1) Or subsoil it 18 inches deep.

(2) Not till the ground is frozen. 


\section{The Raspberry}

The Raspberry likes light and gravelly land, wet, cold soils do not suit it. The soil should be deep and rich; left to itself, the raspberry yields but little fruit; small and without flavor. The care and culture consist in frequent working of the soil, and taking away the branches that have borne fruit. The stem (or cane) grows one year, produces fruit the next, and then dies. Taking off these old canes is done immediately after the crop is gathered. The suckers that start from the root must be considerably reduced in number; otherwise, they would cause confusion and exhaustion of the plants.

The best varieties are:

Caroline.-Fruit yellow, plant vigorous and hardy.

Cuthbert.-Fruit red, plant vigorous; remarkable for the superior quality of the berry, it always brings the highest price.

Golden Queen.--Golden yellow, highly recommended, plant vigorous.

To the above, may be added which may be ranged among the blackberries. (1)

Kittatinny Black Cap.-Fruit very large, flesh rich and excellent. Sets well.

Wauchuset thornless.-Fruit medium size, of good quality. It is an advantage to the two last varieties to pinch off the extremity of the young shoots when they are 10 to 15 inches high, this pinching causes them to

(1) Mûre sanvaye, or, mûre des haies; the mulberry is a largish tree only grown, in England, in the neighborhood of London. Brought in by the French silk-weavers after the revocation of the edict of Nantes. 
send out side branches which increases their production of fruit.

\section{The Gooseberry}

'i'his demands rich, warm soil; it yields abundantly but has to be closely attended to, for if neglected it will send up a multitude of gross feeding shoots, which will absorb all the sap, to the detriment of the fruit. The pruning consists $\ldots$ cutting off these and keeping the interior of the bush open, taking away dead branches or shortening in those which drag on the ground, and prevent the fruit from being gathered.

The best varieties are :

Downing.-Fruit large, pale green, plant vigorous and productire.

Houghton's seedling. - Fruit small, pale red, the plant is vigorous and hardy, and bears in abundance.

Industry.-Fruit rery large. Plant succeeds well and yields well.

Gooseberries are invaded by legions of caterpillars, which quickly destroy all the leaves. When the fruit is partly formed,Parisgreen should be applied; when larger hellebore, $1 \mathrm{oz}$. of powder to 3 gallons of water.

\section{The Currant}

Currants are bunched gooseberries. They will grow in all soils but prefer light land ; the same pruning is required as for tine gooseberry.

The best varieties are:

Cherry.-Fruit large, red, sweet, vigorous.

Fay's prolific.-Red: an abundant bearer.

La Versanlles.-Rose color, slightly acid.

White grape.-White, best for the table. 
Black Champion.-Black, very vigorous in growth.

Lep's Proliflc.-Black, an abundant bearer.

Black Naples. - The best of the three varieties of the black currant.

The same treatment is employed in the destruction of caterpillars as for the gooseberry.

Currants sell well, and from them can be made a syrup much esteemed, and excellent family wine.-(Eugh! A. R. J. F.)

\section{Asparagus}

Asparagus is assuredly a most delicious and wholesome vegetable; its culture is very profitable, when well attended to. Some farmers fancy that its culture is very difficult, and that it demancs exceptional land, abstaining, on that account, from growing it, and are thus deprived of a considerable source of income. Let them try it, and they will soon be convinced that the difficulty is apparent and the profit real.

Purchase of the roots. - The roots of asparagus are called "griffes" by the French, bocause of their similarity in form to a bird's claw. Buy your plants from a trustworthy firm, that makes a specialty of their culture. Nothing gained by sowing the seed and growing the plants ourselves.

Preparation of the soil.-Asparagus prefers caleareous soil of medium consistency, rather light than heavy, and not too moist. With the addition of manure and some calcareous matter we can obtain asparagus in any good soil. When the land is very compact, it is useful to give it a ploughing before the frost 
and leave it so during the winter. In the spring spread the manure and give it another ploughing two spades deep (i.e. 18 inches.)

Planting.-When the land is well ploughed and levelled, place stakes 4 feet apart to form the beds, then open trenches 8 inches deep and 18 inches wide, into these place half rotten manure and mix it with the earth. Now place the little stakes in the trenches to be occupied by the plants, 4 feet apart. and put two or three handfuls of manure opposite each.

When all is prepared make a little mound of earth in the middle of the trench at the place marked to receive the plant which must be placed on this mound and the roots which must not be broken, spread round it ; cover these with one or two inches of earth, making it adhere to their extremities by a little gentle pressure ; then, cover with manure, but without covering the crown, and level the soil-there should be reserved between the lines of trenches a little earth to be levelled the second year.

It is well, after planting, to place a stake by which to recognize where the root is set, so that it may not be injured.

The best season to plant is the month of April or the commencement of May

Never plant in rainy weather, or the roots will rot.

Subsequent care.--The first year, weed and clean the beds, and water them when the season is too dry. In October, at the latest, pull down the little mounds, and top-dress 
the soil with manure. loaving it thus for the winter. As soon as the weather permits in the spring, bury the manure with a flattined digging fork, clearing away carefully the dead loranches, leaving none round the crowns. Bring back the earth which has been mellowed by the frost and which will give an easy passage to the growth of asparagus. Asparagns should not be gathered after the end of June, so as to sare the succeeding crops. In gathering asparagus, it is best to break it off with the fingers.

About the third year, a crop may be cut, but only one or two heads of asparagus from one hill. The fourth year, there may be a full cutting, provided the land be heavily manured afterwards. The third year cut the largest asparagus only. We should not cut the asparagus stalks while they are growing. for we thus destroy a part of the next year's crop. It should only be cut when the leares have turned yellow and have ceased to grow. When we want extra fine plants, pluck off the seeds as soon as formed.

\section{Calendar of work for each month}

January and February. - Look over the fruit room, pack and send off the fruit sold. Tread the snow round the base of the trees to prevent the mice from eating the heart.

March. - Prune the orchard, and do not fail to level and destroy the rings formed by the eggs of the caterpillars. Tread down the snow at the foot of the trees as before.

April. - At the beginning of the month, those who have trees in cellars may prune them and get them ready to plant. Begin 
planting as soon as the snow has disappeared and the land is dry enough. Unmound the apple trees; prepare the land for asparagus.

May.-Finish planting. Unearth the vines and trellis them, level the earth so as to cover the roots. Apply Bordeaux mixture to prerent the Black Knot on the plums and for the apple scab. Employ the American grafting was to cure the wounds made all round the stem by the mice. To re-establish the circulation of sap, forcibly interrupted by the disappearance of the bark, take a piece of a one-year-old branch, a little longer than the width of the bark destroyed, and cut the two extremities like the mouth of a whistle. Slide one into the upper side and the other into the lower side of the injured bark: if required, the bark may be split to facilitate the operation. So long as the splits are on the same generator (sap vessel).

The two extremities of the branch being fastened to the two edges of the wound, the sap can circulate to the extremities of the roots in passing through this branch. If the tree guawn is large, several of these may be introduced.

June.-Finish all planting that is not done, though it be too late: prune the orchard, pinch all premature shoots of the vine, to favour the development of the leading one. Sprinkle the goc:seberries and curıants with hellebore to destroy caterpillars.

July.-Make a second application of Bordeaux mixture to destroy insects and fungi. Apply coal oil emulsion against the greenfly, 
pinch the buds of the vine. Thin the fruit of overloaded apple trees; put props under branches which are bent by the weight of fruit. Gather cherries, gooseberries and currants.

August.-Clean the orchard, gather the first summer apples, yellow transparent, Tetofsky, etc.; prepare the ground and plant strawberries. Prune the fruit branches of the vine to two leaves above the last bunch.

September.-Gather the last summer and the autumn fruits; weed and hoe again, if the summer has been dry.

October.-Gather autumn and winter fruit in fine dry weather. Commence preparing the land for planting the following spring. Those who like to get in their trees in the fall, will receive them this month a store them in the cellar. Earth up and .....e the trees in the orchard, and cut off the broken branches. Gather the grapes, prune the vines for wintering; cut the stems of asparagus.

November.-Continue to prepare the land for spring planting; cover the strawberries with straw or dead leaves.

December.-A ttend to the fruit in the fruithouse; commence drying the fruit. Tread the snow round the trees as before.

G. REYNAUD, Nursery-man to the RR. PP. Trappistes. 


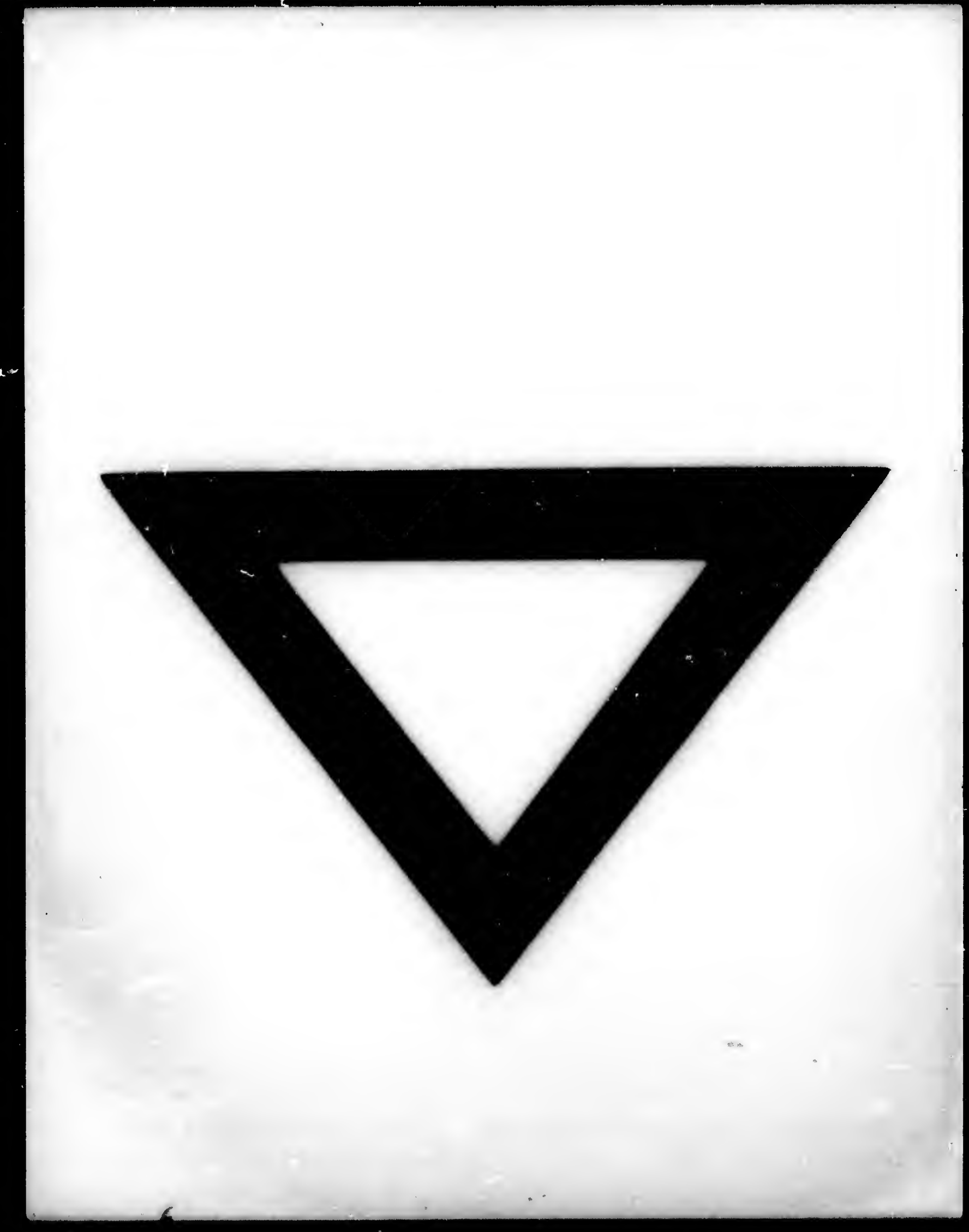

